\title{
Land value-added tax planning of Real estate development enterprises
}

\author{
Haiyan Duan ${ }^{1, a}$, Kaile Zheng ${ }^{2, b}$ \\ ${ }^{1}$ School of Management Henan University of Science and Technology Luoyang, China \\ ${ }^{2}$ School of Management Henan University of Science and Technology Luoyang, China
}

\begin{abstract}
This paper takes the real estate development enterprise as the research object, based on the characteristics of land VALUE-ADDED tax, carries out tax planning on the land value-added tax of the real estate development enterprise from four aspects, including the deduction of interest expense, reasonable pricing, collection cost and whether to combine the real estate with different value-added rates. The conclusion shows that the real estate development enterprises can calculate the tax threshold and choose different tax payment schemes to reduce the tax burden.
\end{abstract}

\section{INTRODUCTION}

For real estate development enterprises, whether the land value added tax can be reasonably planned is a crucial thing in its development process. Land value-added tax refers to the tax burden that should be paid to the state by units and individuals after deduction of legal items when transferring the right to use state-owned land, aboveground buildings and their attached objects, including monetary income, material income and other income, excluding inheritance and donation of real estate without compensation ${ }^{[1]}$. The planning of land value-added tax is to increase deductible items and reduce value-added rate as far as possible under the premise of tax law. This paper analyzes the land value-added tax of real estate development enterprises from four aspects: deduction of interest expense, reasonable pricing, collection mode on behalf of the government and the value-added rate of merging real estate.

\section{REAL ESTATE DEVELOPMENT ENTERPRISES LAND VALUE-ADDED TAX PLANNING}

\subsection{Tax planning with interest deduction}

In the process of real estate development business, real estate development enterprises generally borrow a lot of money, so the interest is inevitable, and different deduction methods of interest will have a great impact on the land value-added tax payable by enterprises. According to the tax law, if the interest expense of financial expenses can be apportioned according to the real estate project transferred and the certificate of financial institution provided, it is allowed to be deducted according to the

aduanhaiyan0813@163.com

b1005618444@qq.com facts, but the maximum amount shall not exceed the amount calculated according to the loan interest rate of the commercial bank for the corresponding period. Other real estate development expenses shall be calculated and deducted within $5 \%$ of the amount of the land use right and real estate development cost paid. If the interest apportionment expense cannot be calculated according to the transferred real estate project or the proof of financial institution cannot be provided, the real estate development expense shall be deducted within $10 \%$ of the land use right payment and the real estate development cost amount ${ }^{[2]}$

\subsubsection{The overall train of thought.}

Real estate development expenses are calculated and deducted in two cases ${ }^{[3]}$. If the interest expense in plan $\mathrm{A}$ is greater than that in Plan B, the enterprise should share the interest expense correctly and provide the financial institution proof; otherwise, the enterprise may not calculate the apportioned interest expenditure in accordance with the transferred real estate development project, or not provide the proof of financial institution, which can increase the deduction amount and reduce the tax basis of land value-added tax ${ }^{[4]}$. Table I shows the detailed planning scheme.

TABLE I. COMPARISON OF PLANNING SCHEMES

\begin{tabular}{|l|l|l|}
\hline \multicolumn{1}{|c|}{ Project } & $\begin{array}{c}\text { Plan A: Deduct the } \\
\text { proportion within 5\% }\end{array}$ & $\begin{array}{c}\text { Plan B: Deduct the } \\
\text { proportion within 10\% }\end{array}$ \\
\hline \multirow{3}{*}{$\begin{array}{l}\text { Developme } \\
\text { nt costs }\end{array}$} & $\begin{array}{l}\text { Interest allowed to be } \\
\text { deducted + (amount } \\
\text { paid for land use rights } \\
+ \text { development costs) } * \\
\text { deductible proportion }\end{array}$ & $\begin{array}{l}\text { (Amount paid for land } \\
\text { use right }+ \text { development } \\
\text { cost)*deducting } \\
\text { proportion }\end{array}$ \\
\hline
\end{tabular}

\subsubsection{Land value added tax planning of M Company.}

Assume that Company M pays 10 million for land and 15 million for development. The local government stipulates 
that the two types of deductions are 5\% and $10 \%$. When the interest payable by $\mathrm{M}$ company is 1.5 million and 1.1 million respectively, the tax planning process is as follows:

\subsubsection{Interest expense payable is 1.5 million:}

Threshold value for deductible interest expenses = (amount paid for land use rights + development costs) * $(10 \%-5 \%)=125$ (Ten thousand). Table II compares the two planning schemes.

TABLE II. COMPARISON OF PLANNING SCHEMES

\begin{tabular}{|l|l|l|}
\hline \multicolumn{1}{|c|}{ Project } & $\begin{array}{c}\text { Plan A: Share the interest } \\
\text { according to the } \\
\text { development project and } \\
\text { provide the financial } \\
\text { institution certificate }\end{array}$ & $\begin{array}{c}\text { Plan B: Do not } \\
\text { share interest or } \\
\text { provide tax } \\
\text { authorities with } \\
\text { certificates of the } \\
\text { financial institutions } \\
\text { concerned }\end{array}$ \\
\hline $\begin{array}{l}\text { Amount to } \\
\text { be paid for } \\
\text { the use of } \\
\text { the land }\end{array}$ & 1000 & 1000 \\
\hline $\begin{array}{l}\text { Developmen } \\
\text { t costs }\end{array}$ & 1500 & 1500 \\
\hline Interest & 150 & 125 \\
\hline $\begin{array}{l}\text { Developmen } \\
\text { t expenses }\end{array}$ & 275 & 250 \\
\hline $\begin{array}{l}\text { Deductible } \\
\text { amount }\end{array}$ & 2775 & 2750 \\
\hline
\end{tabular}

\subsubsection{Interest expense payable is 1.1 million:}

Table III compares the two planning schemes.

TABLE III. COMPARISON OF PLANNING SCHEMES

\begin{tabular}{|l|l|l|}
\hline \multicolumn{1}{|c|}{ Project } & $\begin{array}{c}\text { Plan A: Share the interest } \\
\text { according to the } \\
\text { development project and } \\
\text { provide the financial } \\
\text { institution certificate }\end{array}$ & $\begin{array}{c}\text { Plan B: Do not share } \\
\text { interest or provide tax } \\
\text { authorities with } \\
\text { certificates of the } \\
\text { financial institutions } \\
\text { concerned }\end{array}$ \\
\hline $\begin{array}{l}\text { Amount to } \\
\text { be paid for } \\
\text { the use of } \\
\text { the land }\end{array}$ & 1000 & 1000 \\
\hline $\begin{array}{l}\text { Developmen } \\
\text { t costs }\end{array}$ & 1500 & 1500 \\
\hline Interest & 110 & 125 \\
\hline $\begin{array}{l}\text { Developmen } \\
\text { texpenses }\end{array}$ & 235 & 250 \\
\hline $\begin{array}{l}\text { Deductible } \\
\text { amount }\end{array}$ & 2735 & 2750 \\
\hline
\end{tabular}

It can be judged that when the interest expense is 1.5 million, M Company should adopt plan $\mathrm{A}$, and the interest expense should be deducted according to the actual situation. When the interest expense allowed to be deducted is 1.1 million, the second option should be chosen, which can increase the interest expense of 1.5 ten thousand and reduce the tax based on 1.5 ten thousand, so as to reasonably reduce the tax burden.

\subsection{Tax planning through reasonable pricing}

The tax law stipulates: if the taxpayer builds or sells ordinary standard houses, and the value-added value does not exceed $20 \%$ of the deducted items, the land valueadded tax will be exempted. If the appreciation value exceeds $20 \%$ of the value deducted, tax shall be levied on the entire appreciation value ${ }^{[5]}$. Therefore, we can make full use of the tax burden effect of the critical point of $20 \%$ for tax planning.

\subsubsection{The overall train of thought.}

It is assumed that when the comprehensive appreciation rate of real estate development enterprises is $20 \%$, the selling price is $\mathrm{X}$, the increased price is $\mathrm{Y}, 10 \%$ is the value-added tax rate, $7 \%$ is the urban construction tax rate, and $3 \%$ is the educational surcharge levy rate. Table IV compares the two planning schemes.

\begin{tabular}{|l|l|l|}
\hline \multicolumn{1}{|c|}{ TABLE IV. COMPARISON OF PLANNING SCHEMES } \\
\hline Price & $\begin{array}{c}\text { Plan A: } \\
\text { Preferential } \\
\text { threshold }\end{array}$ & \multicolumn{1}{c|}{$\begin{array}{c}\text { Plan B: To raise } \\
\text { prices }\end{array}$} \\
\hline $\begin{array}{l}\text { Taxes } \\
\text { Surcharges }\end{array}$ & $\mathrm{X}$ & $\mathrm{X}+\mathrm{Y}$ \\
\hline $\begin{array}{l}\text { Allowable } \\
\text { deductions }\end{array}$ & $\begin{array}{l}10 \% *(7 \%+ \\
3 \%) * \mathrm{X}\end{array}$ & $\begin{array}{l}10 \% *(7 \%+3 \%) * \\
(\mathrm{X}+\mathrm{Y})\end{array}$ \\
\hline $\begin{array}{l}\text { Appreciation } \\
\text { forehead }\end{array}$ & $\mathrm{A}-\mathrm{A}-1 \% \mathrm{X}$ & $\begin{array}{l}\mathrm{X}+\mathrm{Y}-\mathrm{A}-1 \% \mathrm{X}- \\
1 \% \mathrm{Y}\end{array}$ \\
\hline $\begin{array}{l}\text { Pricing at maximum } \\
\text { yield }\end{array}$ & $\mathrm{X}=1.2 *$ \\
$(\mathrm{~A}+1 \% * \mathrm{X})$ & $\begin{array}{l}\mathrm{Y}>30 \% *(\mathrm{X} \mathrm{Y}-\mathrm{A}- \\
1 \% \mathrm{X}-1 \% \mathrm{Y})+1 \%\end{array}$ \\
\hline
\end{tabular}

The maximum price is $\mathrm{X}=1.2146 \mathrm{a}$ if the taxpayer is to enjoy the care of the threshold. At this price level, enterprises can not only enjoy the care of the threshold, but also obtain a large profit ${ }^{[6]}$. If the enterprise wants to increase the price to achieve the purpose of increasing the income, at this time the value-added rate is slightly higher than $20 \%$, at this time only when the price increases more than the payment of land value added tax and added taxes and surcharge, price increase is meaningful, at this time the price must meet $\mathrm{Y}>0.0864 \mathrm{a}$.

\subsubsection{M company carries out tax planning through reasonable pricing.}

Given that the house price in the industry is between 17 and 18 million yuan, the land transfer fee paid by $M$ company is 2 million, and the development cost is 9 million. The interest cannot be apportioned according to the real estate development project, nor can it be proved by financial institutions. The deduction ratio of development cost is $10 \%$. Deductible $=200+900+$ $(200+900) * 10 \%+(200+900) * 20 \%=14.3$ million. Table $\mathrm{V}$ shows the tax planning process.

TABLE V. COMPARISON OF PLANNING SCHEMES

\begin{tabular}{|l|c|c|}
\hline \multicolumn{1}{|c|}{ Project } & $\begin{array}{c}\text { Plan A: } \\
\text { Preferential } \\
\text { threshold }\end{array}$ & $\begin{array}{c}\text { Plan B: To raise } \\
\text { prices }\end{array}$ \\
\hline $\begin{array}{l}\text { Pricing at maximum } \\
\text { yield }\end{array}$ & $\mathrm{X}=1430 * 1.2146$ & $\mathrm{Y}>1430 * 0.0864$ \\
\hline
\end{tabular}

The company wants to get the best profit under the preferential threshold, then the highest selling price should be 17.37 million, at this time a profit of 2.90 million. The profit was less than 2.90 million when the price was set between 17 and 17.37 million. If the company wants to raise the selling price appropriately, the price increase must be at least greater than 1.24 million. Therefore, in practice, enterprises can make use of reasonable pricing to maintain a higher competitiveness and obtain a better 
profit. Sometimes the profit brought by a higher price will be lower than the profit brought by a lower price.

\subsection{Tax planning for collection of fees}

According to the tax law, the fees collected by real estate development enterprises at the time of selling houses according to the requirements of the government. If the fees collected are not included in the housing price, but are collected separately, they may not be regarded as the income from transferring real estate, and the fees collected are not allowed to be deducted. If the collection fee is charged to the buyer in the housing price, it shall be taxed as the income obtained from the transfer of the real estate, which may be deducted in the calculation of the deduction amount, but it is not allowed to be used as the base for the additional $20 \%$ deduction ${ }^{[7]}$.

\subsubsection{The overall train of thought.}

There are two ways to collect fees: to collect fees as real estate sales revenue, incorporated into the housing price to the buyer. Or it may charge buyers separately from the housing price ${ }^{[8]}$.

\subsubsection{M company carries out tax planning through collecting fees.}

M company sold the house to obtain sales income of 30 million, and collected various expenses of 2 million. 2 million for land transfer fee, 6 million for real estate development cost, and 2 million for other items that are allowed to be deducted before tax. Table VI shows the tax planning process.

TABLE VI. COMPARISON OF PLANNING SCHEMES

\begin{tabular}{|l|l|l|}
\hline \multicolumn{1}{|c|}{ Project } & $\begin{array}{c}\text { Plan A: The } \\
\text { collection fee is } \\
\text { included in the } \\
\text { price }\end{array}$ & $\begin{array}{c}\text { Plan B: Collection } \\
\text { 3ees are not } \\
\text { included in the } \\
\text { price }\end{array}$ \\
\hline income & \multicolumn{3}{|c|}{$\mathbf{3 0 0 0}$} \\
\hline Deductible amount & 1360 & 1160 \\
\hline $\begin{array}{l}\text { Amount to be paid for } \\
\text { the use of the land }\end{array}$ & 200 & 200 \\
\hline Development costs & 600 & 600 \\
\hline Collecting fees & 200 & 0 \\
\hline $\begin{array}{l}\text { Other deductible } \\
\text { items }\end{array}$ & 200 & 200 \\
\hline Applied to deduct & 160 & 160 \\
\hline Appreciation forehead & 1840 & 1840 \\
\hline Hence & $135.29 \%$ & $158.62 \%$ \\
\hline VAT payable & 716 & 746 \\
\hline
\end{tabular}

Obviously, no matter how the company chooses to collect fees, its appreciation value is 18.4 million, but the adoption of collecting fees into the price will make the deductible items increase by 2 million, thus making the taxpayer pay less tax of 0.3 million, resulting in the reduction of land value added tax payable. When calculating the land value-added tax, land value-added tax is equal to the appreciation forehead multiplied by the tax rate minus the deductible items by simplified deducting coefficient. Whatever collecting way, appreciation is unchanged, would the collecting fees into house prices, increase A project can be deducted, will reduce should pay land value-added tax, if the collecting fee is bigger, can deduct project increases, may also make integral increment rate of decline, bring greater tax benefits to the taxpayer.

\subsection{Whether to merge different value-added rate of real estate.}

In accordance with China's current land value added tax regulations, the calculation of overrate progressive tax rate and deduction coefficient is implemented, as shown in the Table VII.

TABLE VII. TAX RATE AND QUICK CALCULATION DEDUCTION COEFFICIENT

\begin{tabular}{|l|l|l|l|}
\hline $\begin{array}{c}\text { Serie } \\
\text { s }\end{array}$ & \multicolumn{1}{|c|}{ Proportion } & Rate & Simplified coefficient \\
\hline 1 & Less than $50 \%$ & $30 \%$ & 0 \\
\hline 2 & Part of $50 \%-100 \%$ & $40 \%$ & $5 \%$ \\
\hline 3 & Part of $100 \%-200 \%$ & $50 \%$ & $15 \%$ \\
\hline 4 & More than $200 \%$ & $60 \%$ & $35 \%$ \\
\hline
\end{tabular}

\subsubsection{The overall train of thought.}

Land value-added tax is applicable to the four-grade over-rate progressive tax rate. If the comprehensive accounting of houses with different value-added rates is done, it is possible to reduce the applicable tax rate of real estate with high value-added rate, so as to reduce the tax burden of this part of real estate. Meanwhile, the applicable tax rate of real estate with low value-added rate is improved and the tax burden of this part of real estate is increased.

\subsubsection{Tax planning for the consolidated accounting of $M$ company.}

Assuming that Company $\mathrm{M}$ simultaneously develops buildings $\mathrm{A}$ and B.M earns 3 million by selling $\mathrm{A}$, the allowable deduction amount is 2 million. The income from selling B is 4 million, and the allowable deduction amount is 1 million. Table VIII lists the value-added rates of $\mathrm{A}$ and $\mathrm{B}$ in separate accounting and combined accounting.

TABLE VIII. THE VALUE-ADDED RATE OF A AND B CALCULATED SEPARATELY AND COMBINED

\begin{tabular}{|l|l|l|l|}
\hline \multicolumn{1}{|c|}{ Project } & \multicolumn{1}{|c|}{$\begin{array}{c}\boldsymbol{A} \\
\text { Commercia } \\
\boldsymbol{l}\end{array}$} & $\begin{array}{c}\boldsymbol{B} \\
\text { Commercia } \\
\boldsymbol{l}\end{array}$ & $\begin{array}{c}\boldsymbol{A} \text { and } \boldsymbol{B} \\
\text { combined } \\
\text { accounting }\end{array}$ \\
\hline income & 300 & 400 & 700 \\
\hline Deductible amount & 200 & 100 & 300 \\
\hline $\begin{array}{l}\text { Appreciation } \\
\text { forehead }\end{array}$ & 100 & 300 & 400 \\
\hline Hence & $50 \%$ & $300 \%$ & $133.33 \%$ \\
\hline
\end{tabular}

\subsubsection{Separate accounting:}

- A Land value added tax payable $=(300-200)$ $* 30 \%=300,000$ (ten thousand) 
- $\quad$ B Land value added tax payable $=(400-100)$ $* 60 \%-100 * 35 \%=145$ (ten thousand)

- A total of 1.75 million of land value-added tax was paid

\subsubsection{Merger accounting:}

- $\quad \mathrm{A}$ and $\mathrm{B}$ shall pay land value-added tax $=(700-$ $300) * 50 \%-300 * 15 \%=155$ (ten thousand)

It can be seen from the comparison that the consolidated accounting is beneficial to the company, because the consolidated accounting is more tax-efficient than the separate accounting of 20 ten thousand.

From the above tax planning case, we can see that due to the large difference in the value-added rate of the two types of real estate, as long as the real estate development company arranges the development and sale of the two buildings together, and at the same time the income of the two types of real estate and deduction items combined accounting, it can achieve the purpose of less tax. However, as the tax rate of low-value-added property may be increased, the choice can only be made after specific calculation in practice.

\section{CONCLUSION}

This paper analyzes the land value added tax planning of real estate development enterprises from four aspects: deduction of interest expenses, reasonable pricing, collection cost and consolidation of real estate with different value-added rates. The following conclusions are drawn:

- In the tax planning of land value-added tax using the interest deduction standard, the critical point of interest deduction is calculated and compared with the actual interest deduction, so as to judge whether an enterprise needs to share the interest according to the real estate development project and provide the proof of financial institutions.

- The tax planning of land value added tax is carried out through reasonable pricing. Firstly, the tax critical point is calculated to understand the maximum benefit of the preferential threshold and the appropriate range of price increase. Then, combined with the housing price in the industry, the highest selling price under the best profit is selected.

- According to the tax planning of collection fees, if the value-added rate is $\leq 50 \%$, no matter what collection method is adopted, the tax burden of taxpayers will be the same. If the value-added rate $>50 \%$, compare the tax burden under the two situations of whether the collection fee is included in the housing price, and judge the choice of collection method.

- As different value-added rates correspond to different value-added tax rates, enterprises can change their value-added rates through consolidated accounting of real estate, and compare with the tax burden under separate accounting, in order to achieve the purpose of tax planning.

The tax issues involved in each link of real estate development are relatively complex, not every tax planning method is absolutely feasible, they all have certain applicable conditions and limitations. Therefore, the actual work still needs to be combined with the actual situation of the enterprise, specific problems specific treatment.

\section{ACKNOWLEDGMENT}

We thank the members of the Technical Innovation and Knowledge Management Research Group for their support and valuable discussion. In addition, we would like to thank Baofeng Li for inspiring my topic in his tax law course.

\section{REFERENCES}

1. J. Liang. Discussion on land value added tax planning of real estate development enterprises[J]. Contemporary accounting, 2017(03): pp. 40-41.

2. L. G. Qiao. A case study of land value-added tax planning of real estate development companies[J]. Friends of the accounting, 2016(03): pp. 67-70.

3. Y. D. Shan. Tax planning case analysis of real estate enterprises[J]. Accounting of China's Township enterprises, 2018(10): pp. 45-47.

4. J. W. Hu. Case study of company land value added tax planning[J]. Housing and real estate, 2016(18): pp. 7.

5. B. Lu. Analysis of land value added tax planning of real estate enterprises $[\mathrm{J}]$. Certified public accountants, 2013(08): pp. 48-49.

6. H. Y. Wu. Reflections on the Planning Model of Land value added Tax in real estate enterprises [J]. Tax, 2018(17): pp. 6-7.

7. M. M. Li. Land value added tax planning of real estate enterprises[J]. Accounting communication, 2015(29): pp. 120-122.

8. Y. Liu. A Brief discussion on the planning method and applicable conditions of land value added Tax after "Replacing business tax with value-added Tax" -Taking real estate enterprises as an example[J]. Theory of China, 2017(04): pp. 145-147. 